\title{
Assessing changes in saltwater intrusion in some main rivers of Vinh Long province
}

\author{
- Le Ngoc Tuan \\ - Phan Ngoc Minh \\ University of Science, VNU-HCM \\ (Received on $22^{\text {th }}$ December 2016, accepted on $30^{\text {th }}$ October 2017)
}

\begin{abstract}
ASBTRACT
Saltwater intrusion (SI) associated with El Nino phenomenon is a particularly concerned issue in a period of 2015-2016. Salinity evolutions in the Mekong Delta and Vinh Long province are becoming serious. Therefore, this work aimed at assessing changes in saltwater intrusion in Vinh Long province during recent ten years (2007-2016), including changes in the highest, the lowest, and average salinities. Besides, 19 surface water samples were collected and analyzed to evaluate the current status of
\end{abstract}

salinization in 2016. Results showed that the salinity tends to propagate into the infield, especially in Co Chien River (0.4 to $1.2 \%$ ), followed by Hau River (0.2 to $0.7 \%$ ) and other inland waterways (0.3-0.6\%), leading to certain impacts on agriculture, aquaculture, and water supply in the local in general. In Vinh Long province, Vung Liem and Tra On districts were relative significantly influenced by SI, requiring suitable control measures, particularly in the context of climate change.

Key words: saltwater intrusion, climate change, salinity

\section{INTRODUCTION}

In the context of climate change (CC), many areas around the world are facing to disasters such as heavy storms, flood, drought, saltwater intrusion (SI), etc. leading to serious damages. According to The Australian Foundation for the Peoples of Asia and the Pacific (AFAP) Vietnam [1], to the end of the $21^{\text {st }}$ century, if $\mathrm{CC}$ is not effectively reduced, VietNam will lose at least $12.2 \%$ of land, where $23 \%$ of the population are living, leading to serious affects to low delta areas - one of the most important granaries of the world by flood and SI. CC and sea level rise make SI evolution more and more complex. Salinity tends to propagate into the inland, affecting the socio-economic activities such as agriculture [2], aquaculture, using water [3, 4] and natural ecosystems, etc. This is one of the major challenges in Vietnam. Drought and SI were very harsh in the MeKong delta in the dry season of 2015-2016, SI came soon, significantly entered the inland and extended until mid of 2016. Studies showed SI tends to propagate into the estuaries, mainly due to (i) lack of additional water from the upstream and (ii) rising tendency of water level from the downstream [5]. Besides, the important factors (natural and artificial) affecting the SI process could include tide [6-9], temperature, precipitation $[6,9]$, northeast wind [6], terrain [8, 10], construsting and operating reservoirs [8], socio-economic activities [8, 1012].

Vinh Long one of the agricultural provinces in the MeKong delta, specializing in growing rice, fruit trees, and freshwater aquaculture - is located along the Tien river and Hau river. Terrain is relatively flat, lower from north to south, and relatively low as compared to the sea level. The infrastructure, farming conditions, economic growth, living traditions, etc. 
intimately connect to nature, so Vinh Long province is very sensitive to effects of weather and SI, especially in the context of CC. Therefore, changes in SI in Vinh Long province need more concerning due to its direct and indirect impacts on daily life and agricultural production etc. Therefore, this research mainly aimed at assessing changes in SI on main rivers in Vinh Long province (Co Chien river, Hau river, Mang Thit river, and Tra Ngoa canal) during recently ten years (2007-2016), including changes in the highest, the lowest, and average salinities; assessing preliminarily impacts of SI on socio-economic sectors in the province, creating the basis for proposing suitable management solutions, reducing SI impacts, and contributing to sustainable development strategy of the area.

\section{METHODS}

On the basis of monitoring data, changes in salinity in main rivers in Vinh Long province were assessed via:

Characterized salinity: the daily highest salinity (2007-2013), the daily lowest salinity (2007-2011), the yearly highest salinity (20072016).

Assessed aspects: changes in salinity by the time, the saltiest month of the year, the saltiest day of the month and the variation by the time.

\section{Data collection and processing}

Related data and documents were collected at the agencies and departments in Vinh Long province to assess changes in SI and impacts to socio-econimic activities (planting, fisheries, water supply, etc.). Salinity data (hourly and daily) monitoring in March to May at Vung Liem, Nang Am, Tich Thien, and Nga Tu stations in the period of 2007-2011 and 2012-2016 were collected from the VinhLong Hydrometeorology station and the Vinh Long Department of Natural Resources and Environment, respectively while the daily highest salinity data in 2016 at 4 mentioned stations and Quoi An station was collected from the Vinh Long Department of Agriculture and Rural Development, etc. to assess changes in SI.

\section{Monitoring method}

Salinity monitoring method was used to assess the current status of SI in some main rivers of Vinh Long province in 2016. 19 sampling locations (Fig. 1) were distributed in Co Chien river, Hau river, Vung Liem river, and Mang Thit river. Sampling time was on 22 - 23/3/2016 (dry season). QCVN 08-MT:2015/BTNMT - National technical regulations on surface water quality was then used to compare and assess the salinity.

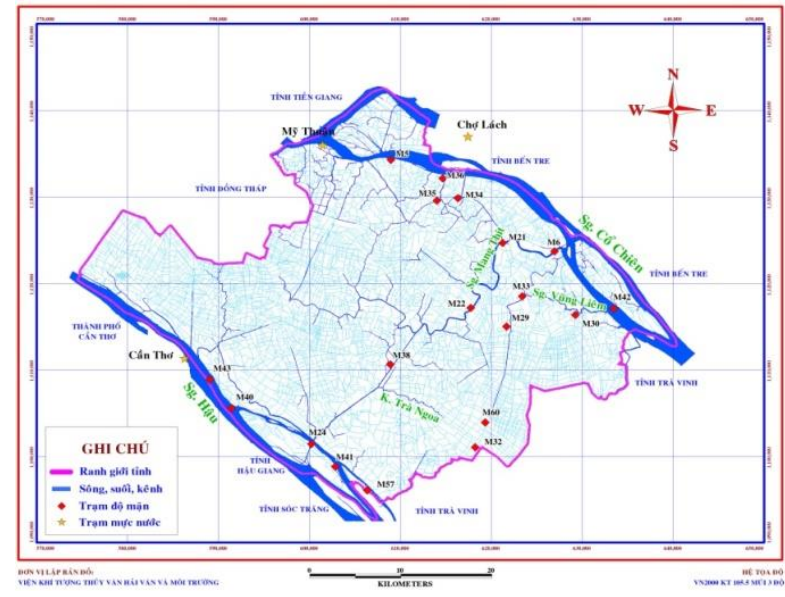

Fig. 1. Water level and salinity monitoring stations

\section{GIS method}

Mapinfo and Surfer 10.0 software were used to draw maps, show monitoring locations, draw salinity boundary, and overlay landuse maps and salinity boundary to assess SI impacts.

\section{RESULTS}

Change in SI in Vinh Long province in the period of 2007-2016

Previously, SI was not the concern in Vinh Long province. However, in context of the complicated changes in weather and climate combining with the longest period of El Nino in

Trang 266 
history (from the end of 2014 to 2016), etc. SI manifestations are increasingly clear, monitoring salinity data were much higher than that in previous years. Some salinity characteristics in the period of 2007-2013 were show in Table 1.

Table 1. Some salinity characteristics in the period of 2007-2013

\begin{tabular}{|c|c|c|c|c|c|}
\hline \multirow{2}{*}{\multicolumn{2}{|c|}{ SALINITY (\%) }} & \multicolumn{2}{|c|}{ Co Chien River } & \multirow{3}{*}{$\begin{array}{c}\text { Hau River } \\
\text { Tich Thien St. } \\
0.2\end{array}$} & \multirow{3}{*}{$\begin{array}{l}\text { Tra Ngoa Canal } \\
\text { Nga Tu St. } \\
\end{array}$} \\
\hline & & Vung Liem St. & Nang Am St. & & \\
\hline \multirow{21}{*}{$\begin{array}{ll} & \text { Aver } \\
\text { age } & \text { day } \\
\max \end{array}$} & Dry season 2007 & 0.4 & 0.7 & & \\
\hline & The saltiest month & April (0.8) & April (1.1) & April (0.5) & April (0.41) \\
\hline & Salty peak & $21 / 04$ (1.6) & $07 / 05(3)$ & $22 / 04(1.9)$ & $11 / 04(0.6)$ \\
\hline & Dry season 2008 & 0.4 & 0.6 & 0.2 & 0.3 \\
\hline & The saltiest month & March (0.5) & March (0.6) & March (0.3) & March (0.3) \\
\hline & Salty peak & $06 / 03(2.3)$ & 06/03 (2.5) & 03/03 (1.4) & 04/03 (0.9) \\
\hline & Dry season 2009 & 0.5 & 0.7 & 0.2 & 0.3 \\
\hline & The saltiest month & April (1.1) & April (1.5) & April (0.2) & March (0.25) \\
\hline & Salty peak & 23/04 (3.8) & $24 / 04(4.5)$ & 28/04 (0.5) & 28/03 (1.0) \\
\hline & Dry season 2010 & 0.9 & 1.2 & 0.6 & 0.5 \\
\hline & The saltiest month & April (1.1) & April (1.6) & April (1.0) & April (0.63) \\
\hline & Salty peak & $30 / 03(5.2)$ & $30 / 3(5.4)$ & $29 / 03$ (3.6) & $09 / 04(1.3)$ \\
\hline & Dry season 2011 & 0.8 & 1.1 & 0.7 & 0.6 \\
\hline & The saltiest month & March (1.2) & March (1.4) & March (1.13) & April (0.75) \\
\hline & Salty peak & $02 / 4(4.9)$ & $31 / 03(4.5)$ & $01 / 04(4.9)$ & $05 / 04(1.6)$ \\
\hline & Dry season 2012 & 0.5 & 0.7 & 0.2 & 0.3 \\
\hline & The saltiest month & April (1.0) & April (1.3) & March (0.3) & April (0.28) \\
\hline & Salty peak & $03 / 4(3.8)$ & $03 / 04(3.8)$ & $10 / 04(0.9)$ & $16 / 04(0.8)$ \\
\hline & Dry season 2013 & 0.7 & 0.9 & 0.2 & 0.4 \\
\hline & The saltiest month & April (1.05) & April (1.3) & April (0.32) & April (0.4) \\
\hline & Salty peak & $22 / 4$ (3.9) & $22 / 04(4.1)$ & $28 / 04(0.9)$ & $01 / 03(0.7)$ \\
\hline \multirow{5}{*}{$\begin{array}{c}\text { Average } \\
S_{T B}^{d a y}\end{array}$} & Dry season 2007 & 0.2 & 0.3 & 0.1 & 0.3 \\
\hline & Dry season 2008 & 0.2 & 0.3 & 0.1 & 0.3 \\
\hline & Dry season 2009 & 0.3 & 0.4 & 0.1 & 0.2 \\
\hline & Dry season 2010 & 0.5 & 0.7 & 0.4 & 0.4 \\
\hline & Dry season 2011 & 0.4 & 0.6 & 0.4 & 0.5 \\
\hline \multirow{5}{*}{$\begin{array}{l}\text { Average } \\
S_{\min }\end{array}$} & Dry season 2007 & 0.1 & 0.1 & 0.1 & 0.2 \\
\hline & Dry season 2008 & 0.1 & 0.2 & 0.1 & 0.2 \\
\hline & Dry season 2009 & 0.1 & 0.3 & 0.1 & 0.2 \\
\hline & Dry season 2010 & 0.2 & 0.3 & 0.2 & 0.3 \\
\hline & Dry season 2011 & 0.1 & 0.3 & 0.2 & 0.4 \\
\hline
\end{tabular}

Evolution of the daily highest salinity (Smax) in the period of $2007-2013$

Salinities in Co Chien river (monitored at Vung Liem and Nang Am stations) in the period of 2007-2013 relative significantly changed. Overall, average $S_{\max }$ tended to inscrease from 0.4 to $0.9 \%$. Salty peaks often appeared at the end of March or the last 10 days of April, ranging 
from 1.1 to $1.6 \%$. In 2010 and 2011, because of heavy drought, salty peak reached $5.2 \%$ (Vung Liem station) and $5.4 \%$ (Nang Am station). $\mathrm{S}_{\max }$ in Hau river (monitored at Tich Thien station) was relatively stable, ranging from $0.1-0.5 \%$ except 2010 and 2011 with many changes: in 2010, salinity was the highest in April; in 2011, March was in turn with 2 times of heavy salinization, average $S_{\max }$ reached $1.13 \%$. In Tra Ngoa canal, representing infield areas (monitored at Nga Tu station), $S_{\max }$ in the period of 2007 2013 insignificantly changed, ranging from 0.3 to $0.4 \%$. In 2011, a dry year, the salinity of infield areas reached $1.6 \%$.

Evolution of the daily average salinity (STB) in the period of 2007-2011

In the period of 2007-2011, $\mathrm{S}_{\mathrm{TB}}$ in Co Chien river tended to increase (from 0.2 to $0.5 \%$ ). In Hau river, salinity in the period of 2010 - 2011 ranged between 0.5 and $0.7 \%$. $\mathrm{S}_{\mathrm{TB}}$ in Tra Ngoa canal were not much different by the years, ranging from 0.2 to $0.4 \%$

Evolution of the daily lowest salinity (Smin) in the period of 2007-2011

Evolution of $S_{\min }$ in main rivers of Vinh Long province in dry season ranged from 0.1 to $0.4 \%$ over the years. In Hau River, $\mathrm{S}_{\min }$ increased from 0.1 to $0.3 \%$ in the period of 2007-2011. In Co Chien river, average $S_{\min }$ was about $0.16 \%$ in the whole dry season. In Tra Ngoa canal, the evolution was more complicated. Due to being located in infield area, average $S_{\text {min }}$ were lower than those in other stations, ranging from 0.1 to $0.4 \%$.

Evolution of the yearly highest salinity (Smaxyear) in the period of 2007-2016

The yearly highest salinity in main rivers of Vinh Long province in the period of 2007 - 2016 was shown in Fig. 2. Evolution of maximum salinity over the years 2007, 2010, 2013, 2016 were shown in Fig. 3.

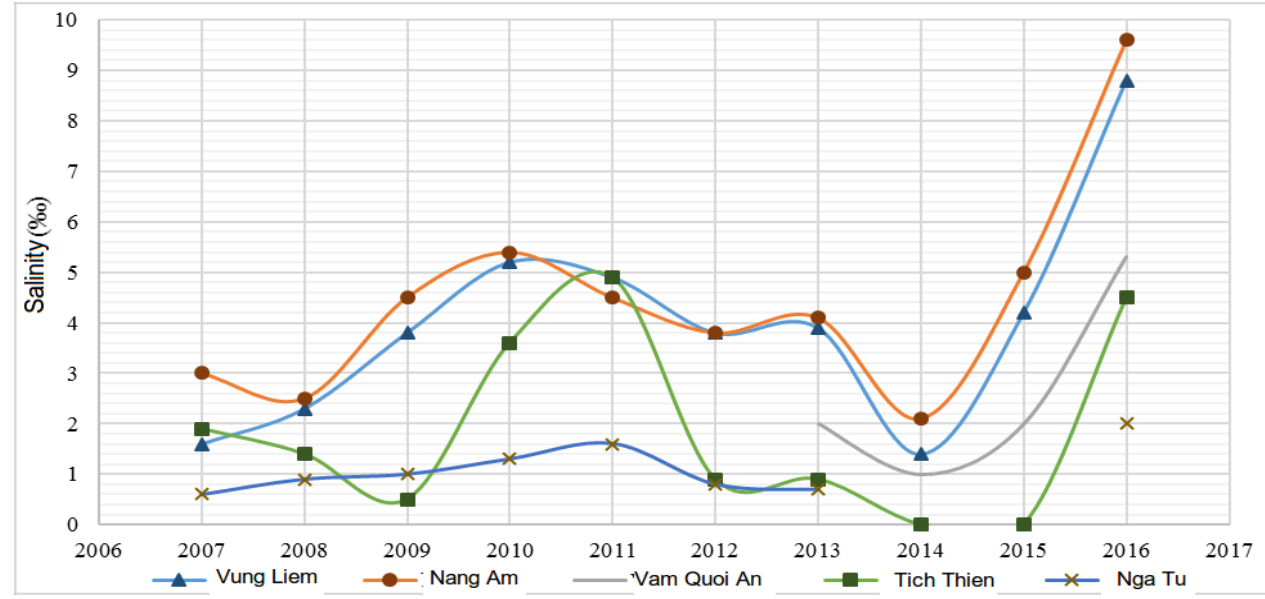

Fig. 2. Evolution of the yearly highest salinity in the period of 2007-2016 


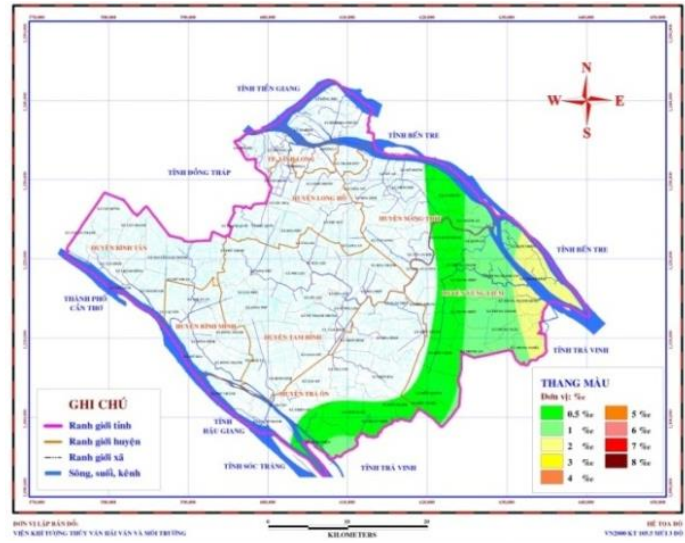

(A)

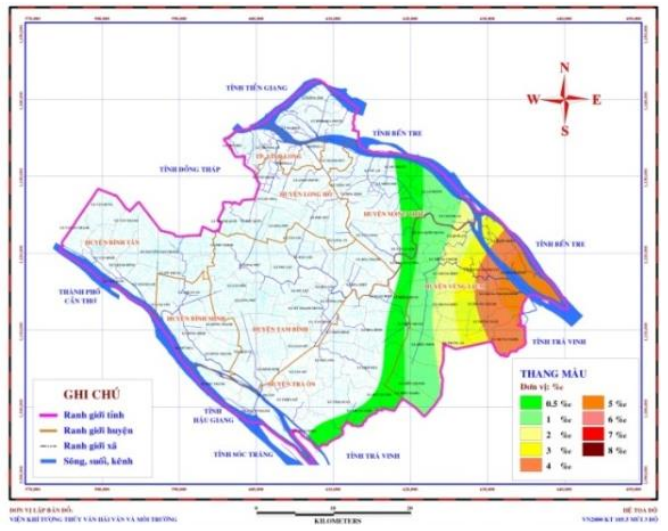

(C)

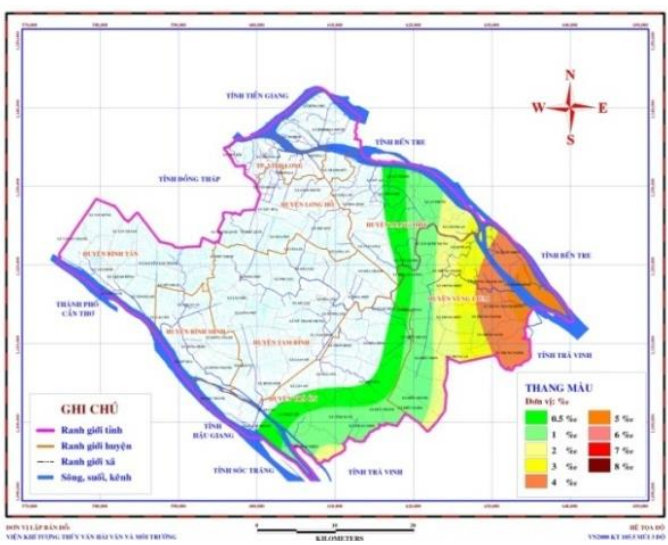

(B)

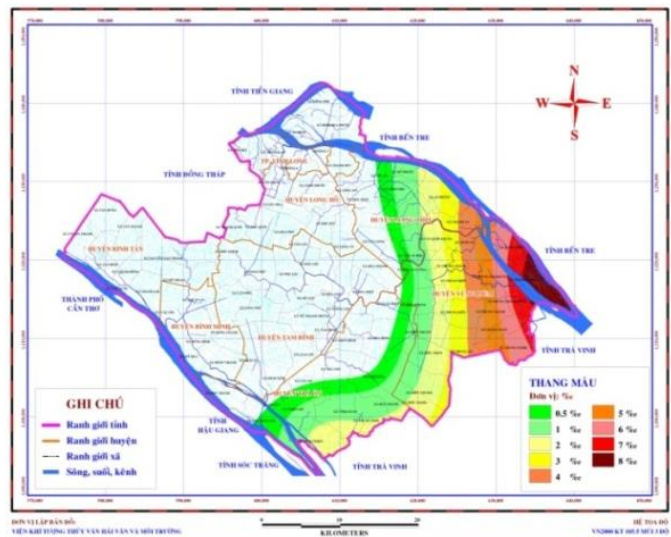

(D)

Fig.3. Distribution of maximum yearly salinity in main rivers of Vinh Long province: (A) 2007, (B) 2010, (C) 2013, (D) 2016

Overall, SI in main rivers tended to increase and spread into the infield. Especially in 2016, higher salinities appeared: $2 \%$ salty boundary started to affect Hau river, Vung Liem district, Mang Thit district, and Tra On district; 8 \% salty boundary was also recorded in Vung Liem district. It could partly correspond to the increasing trend of water level in Vinh Long, especially in Can Tho station (about $0.93 \mathrm{~cm} /$ year for the period of $1978-2015$ ).

Monitoring data in March of 2016 showed salinity ranged from 0.3 to $0.8 \%$, being able to affect water supply plants. In Co Chien river, salinity increased from M5, M36 to M42 (increasing toward the sea): 0,3-0,8\%o. Salinities at M34, M35 (in infield channels) and M36 (in
Co Chien river) had relatively similar, indicating the possibility of SI in infield areas following the increase in salinity in Co Chien river. In $\mathrm{Hau}$ river, differences in salinitiy among monitoring positions were negligible, ranging from 0.5 to 0.6 $\%$ and tended to increase toward the sea. Salinities in Mang Thit river (connecting Co Chien and Hau river) were similar among stations, ranging from 0.35 to $0.47 \%$. Vung Liem river is located infield and rather short, consequently, salinities were relatively similar among M29, M30 and M33 stations, ranging around $0.5 \%$. Noted that salinities in small channels (near Tra Vinh province) were relatively high such as: Tra Ngoa cannal (1.2 \%o) and Nga Chanh cannal $(0.8 \%)$. 
Preliminary assessment of impacts of SI to some socio-economic activities in Vinh Long province

\section{Impacts of SI to the agricultural sector}

Salty water spreading into inland can affect crops (make flowers and fruits fall during flowering-fruiting period or kill shrubs, etc.). Besides, SI can cause the decline of agricultural areas, leading to crop yield decrease. Based on the current status of land use and SI at Vinh Long province, calculated results of perennial and rice planting areas potentially affected by SI showed
Vung Liem to be the most affected area by SI (Table 2). SI significantly affected agricultural sector of Vinh Long province, especially the cultivation one. The breeding sector was not directly affected by SI but facing the consequences related to water and food resources, diseases, etc. In the context of climate change, SI will increase, leading to the lack of water for crop, difficulties of farming conditions, high risks of epidemic diseases, etc. and then affecting the economy and food security.

Table 2. Calculated results of the current status of perennial and rice planting areas potentially affected by SI at Vung Liem District

\begin{tabular}{|c|c|c|c|}
\hline Object & \multicolumn{2}{|c|}{ Salinity and salinization area } & Value \\
\hline \multirow{5}{*}{ Rice } & \multirow{2}{*}{$\geq 2 \%$} & Salinization area (ha) & $7,002.86$ \\
\hline & & Rate (\%) & 47.24 \\
\hline & \multirow{2}{*}{$\geq 4 \%$} & Salinization area (ha) & 767.28 \\
\hline & & Rate (\%) & 5.18 \\
\hline & \multicolumn{2}{|c|}{ Total rice area $(\mathrm{ha})$} & $14,824.06$ \\
\hline \multirow{7}{*}{$\begin{array}{l}\text { Perennial } \\
\text { plants }\end{array}$} & \multirow{2}{*}{$\geq 2 \%$} & Salinization area (ha) & $2,062.51$ \\
\hline & & Rate $(\%)$ & 64.42 \\
\hline & \multirow{2}{*}{$\geq 4 \%$} & Salinization area (ha) & 257.42 \\
\hline & & Rate $(\%)$ & 8.04 \\
\hline & \multirow{2}{*}{$\geq 7 \%$} & Salinization area (ha) & - \\
\hline & & Rate $(\%)$ & - \\
\hline & \multicolumn{2}{|c|}{ Total perennial plant area $(\mathrm{ha})$} & $3,201.85$ \\
\hline
\end{tabular}

\section{Impacts of SI to aquaculture}

The increase in SI leads to the increase in impacts to fresh water aquacultural areas. Significant changes in salinity make organisms cannot adapt to the new environment, inhibit development, reduce fertility or even make mortality. On the other hand, when the sea level rises, aquaculture area of brackish can be expanded. However, at the present no greater benefits are achieved because water quality in these areas are often degraded. The popular aquacultural species in Vinh Long province such as Pangasius catfish, Basa fish, Red tilapia, and shrimp have large salt tolerance threshold, <12 $\%$, $<28 \%$ and $<25-33 \%$, respectively. Therefore, SI has not been an alarming issue for aquacultural sector in the local (Fig. 4). However, SI can change the water quality and increase risks of developing some pathogens for aquacultural species.

Impacts of SI to water supply sector

There are 4 types of water supply at Vinh Long province: (i) centralized water supply; (ii) rainwater; (iii) wells; (iv) rivers and lakes. People living in the infield areas usually use water from

\section{Trang 270}


rivers and rainwater for bathing, washing, and other domestic activities. Overall, the rate of people using centralized water supply services is still low (average of $55 \%$ ), especially in Tra On and Vung Liem districts corresponding to $29.8 \%$ and $52 \%$, respectively [15]. Meanwhile SI in these districts are increasingly serious, $2.5 \%$ in the infield area of Vung Liem district and $1 \%$ in Tra On district, leading to risks for water supply facilities (Table 4, Fig. 4), lack of domestic water, subsequently affecting the health (intestinal diseases, skin diseases, etc.) and living activities of people. It could be inferred the sensitivity to SI (especially in climate change context) of the domestic water supply sector in Vinh Long province is increasing, and thus needs detailed investigating.

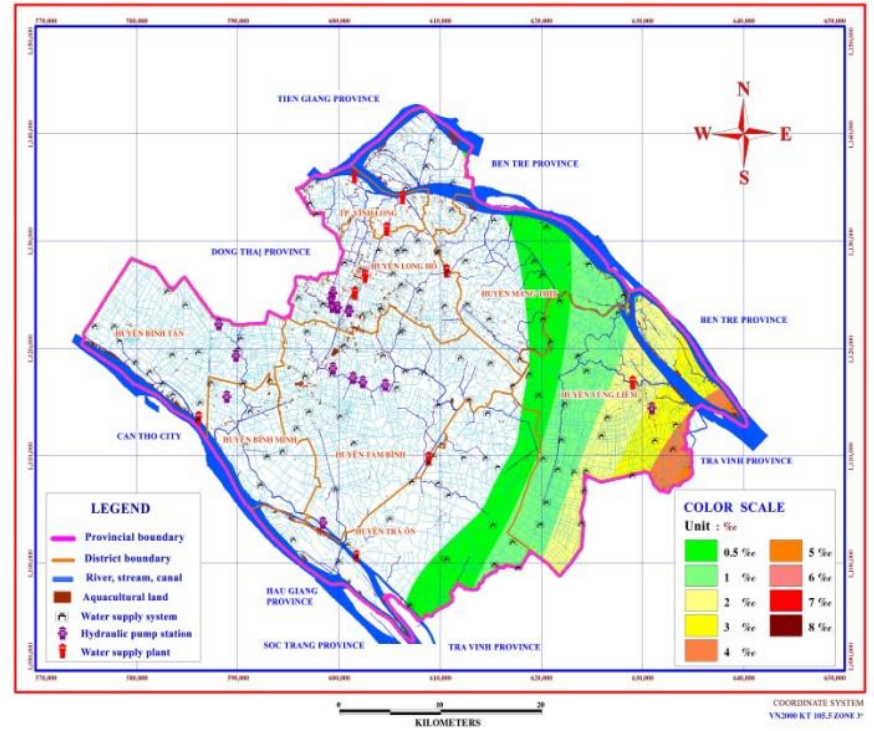

Fig.4. The current status of aquacultural areas and water supply systems in the salty areas in Vinh Long province

Table 4. The current status of water supply facilities potentially affected by SI

\begin{tabular}{|l|l|l|l|l|}
\hline \multirow{2}{*}{ District } & \multicolumn{4}{|l|}{ Current status } \\
\cline { 2 - 5 } & Water supply plant & Water supply system & Water supply station & Total \\
\hline Mang Thit & - & 6 & - & 6 \\
\hline Vung Liem & 1 & 23 & 1 & 25 \\
\hline Tra On & - & 7 & - & 7 \\
\hline
\end{tabular}

\section{CONCLUSION}

SI evolution (the highest, the lowest, and the average salinities) at Vinh Long province during 2007 - 2016 tended to increase; salinity in March is often the highest; salinity peak usually appears from the end of March to the beginning of April. Monitoring results in March of 2016 recorded the increase in salinities as compared to those in the previous years. The salinity in Co Chien River was the highest, impacting Vung Liem, Tra On, and Mang Thit districts. Therefore, assessing vulnerability to SI of specific sectors needs carrying out, serving propose appropriate control measures, ensuring response effectively to SI, especially in the context of climate change. 


\section{Đánh giá diễn biến xâm nhập mặn trên các sông chính ở tỉnh Vĩnh Long}

- Lê Ngọc Tuấn

- Phan Ngọc Minh

Trường Đại học Khoa học Tự nhiên, ĐHQG-HCM

\section{TÓM TẮT}

Xâm nhập mặn (XNM) là vấn đề đáng quan tâm trong năm 2015-2016 cùng với hiện tương El Nino. Diễn biến XNM tại đồng bằng sông Cưu Long nói chung và tỉnh Vĩnh Long nói riêng đang ngày càng trầm trong. Nghiên cúu nhằm muc tiêu đánh giá diễn biến XNM trên các sông chinh ở tỉnh Vĩnh Long trong 10 năm gần đây (20072016), bao gồm diễn biến độ mặn cao nhất, thấp nhất và trung bình; kết hợp lấy mẫu nước mặt tại 19 vị trí nhằm đánh giá hiện trạng mặn trong năm 2016. Kết quả cho thấy, mặn có xu huoóng

Tù khóa: xâm nhập mặn, biến đổi khi hậu, độ mặn

\section{REFERENCES}

[1]. The Australian Foundation for the Peoples of Asia and the Pacific - AFAP Vietnam. Strengthening the adaptive capacity to climate change (2015). Avaible at: http://www.afap.org/afap-vietnamvietnamese/afap-viet-nam-climate-change/ (accessed on 06.08.2016)

[2]. N.H. Dan et al., Forecasting impacts of sea level rise and salinization under climate change scenarios to rice cultivation in the Mekong River delta, Journal of Science and Technology, Agriculture and Rural Development, 1, 9-16 (11/2014).

[3]. P.M. Barlow, Ground Water in Freshwater - Saltwater Environments of the Atlantic Coast (2003). Avaible at: http://pubs.usgs.gov/circ/2003/circ1262/ (Accessed on 05/12/2016).

[4]. T.Q. Dat, N.H. Trung, K. Likitdecharote, Simulating saltwater intrusion in the Mekong Delta under impacts of sea level

lấn sâu vào nộ đồng, nhiều nhất phía sông Cồ Chiên (trung bình mùa khô qua các năm dao động tù 0,4-1,2\%o), tiếp theo là sông Hậu (0,2$0,7 \%$ ) và các kênh rạch vùng nộ đồng $(0,3-0,6$ $\%$ ) - ảnh huởng nhất định đến ngành trồng trọt, nuôi trồng thủy sản và hoạt động cấp nước sinh hoạt. Trên địa bàn tỉnh Vĩnh Long, các khu vục đáng quan tâm trong mối quan hệ với XNM là huyện Vũng Liêm và Trà Ôn, theo đó, đòi hỏi nhũng biện pháp kiểm soát và thich ứng phù hợp, đặc biệt trong bối cảnh biến đổi khi hậu.

rise and the decline in upstream flow, Journal of Science - Can Tho University, 21b, 141-150 (2012).

[5]. P.T. Thang, N.T. Hien, Impacts of climate change and sea level rise on saltwater intrusion in coastal zones in North Delta, Journal of Irrigation Techniques and Environment, 37, 34-39 (2012).

[6]. L.A. Tuan, Curriculum of Environmental Hydrology, Can Tho University (2008).

[7]. V.H. Hoa, L.H. Dung, Studying and forecasting the saltwater intrusion trend due to sea level rise in North coastal estuaries, Journal of Water Resources University, 27, 67-78 (2009)

[8]. N.B. Duong, D.C. San, P.D. Nghia, Analysis of the relationship between the amount of water flushing down the Saigon river from Dau Tieng reservoir and the saltwater flush effectiveness, Southern

Trang 272 
Institute of Water Resources Research (2009).

[9]. L.T.T. Van, N.N. Truong, Identifying factors affecting the saltwater intrusion in the Mekong River Delta in recent years, Deparment of Geology, University of Science, Vietnam National University Ho Chi Minh City (2014).

[10]. L.M. Phung et al., Using the 1D hydraulic mathematical model to assess and forecast salinisation on main river systems in Tra Vinh province, Journal of Science - Can Tho University, 25, 68-75 (2013).

[11]. L.A. Tuan, L.Q. Tri, N.H. Trung, L.V. Du, V.P.D. Tri, The project of enhancing resilience of CanTho city to cope with salinization due to climate change. Component 3: Determining salinity intrusion thresholds and response actions,
CanTho Climate Change Coordination Office (CCCO) (8/2012).

[12]. D.N. Thuc et al., Saline intrusion in Quaternary aquifer sediments in the coastal plain of $\mathrm{Ha}$ Tinh province. Journal of Science and Technology, Water Resources and Environment, 50, 37-44 (2015).

[13]. IPCC, Climate Change: Synthesis Report Summary for Policymakers, Assessment of Working Groups I, II and III to the Third Assessment Report of the IPCC, Cambridge University Press (2007).

[14]. IPCC, 2013, Fifth Assessment Report: Climate Change 2013 (AR5-WG1). Available at: http://www.climatechange2013.org/images/ report/WG1AR5_SPM_FINAL.pdf

[15]. People's Committee of Vinh Long province. Socioeconomic Report (2014). 